\title{
Country Image, Destination Image, Self-Congruity, and Revisit Intention to Singapore: The Mediating Role of Memorable Tourism Experience
}

\author{
Natasia Natasia ${ }^{1}$ Hetty Karunia Tunjungsari ${ }^{1 *}$ \\ ${ }^{l}$ Faculty of Economics and Business, Universitas Tarumanagara, Jakarta, Indonesia \\ ${ }^{*}$ Corresponding author. Email: hetty@fe.untar.ac.id
}

\begin{abstract}
The purpose of this study is to examine whether country image, destination image, and self-congruity have significant effect on tourist's revisit intention to Singapore. This study also proposed the mediating role of memorable tourism experience in the effect of country image, destination image, and self-congruity on revisit intention to Singapore. Sample was collected using a non-probability sampling and convenience sampling method. There were 200 respondents voluntarily participated in an online survey. Research findings show that all hypotheses were supported by data, except self-congruity that has no influence on memorable tourism experience. Country image, destination image, and self-congruity have significant effect on revisit intention of Singapore. Research also finds the mediating effect of memorable tourism experience in the effect of country image, destination image and self-congruity on revisit intention to Singapore. Theoretically, this research findings will invigorate previous studies in destination marketing, especially in the case of tourist's revisit intention. In practical terms, research findings can become input for Singapore Tourism Board to be able to develop tourism programs that can encourage memorable tourism experience.
\end{abstract}

Keywords: country image, destination image, self-congruity, revisit intention, memorable tourism experience

\section{INTRODUCTION}

The tourism sector is one sector that is in great demand by consumers (tourists) from various circles. This sector includes travel activities to various tourist destinations both domestically and abroad. In the period before the COVID19 pandemic hit the world widely, Indonesian tourists also visited various destinations abroad. One of the countries that is a favorite destination for Indonesian tourists is Singapore. Singapore is located not far from Indonesia and is relatively easy to access. This country offers a variety of tourism options, both shopping, medical, MICE, and even nature tourism.

According [1], many Indonesian tourists state that Singapore is a disciplined country and highly values time. This is known from several tourists who have visited Singapore. Moreover, [2] also mentions that Singapore is also an orderly country. This can happen because of the causative factors if you do not obey the rules properly, for example, such as a very large fine if someone is caught littering. The fine is around 1,000 Singapore dollars [3].

There is interest in Singapore that allows tourists to adjust themselves because Singapore is ranked in the top ten as a clean country in the world [1]. This gives speculation that tourists feel very comfortable and happy when traveling from one place to another and make for a good and enjoyable tourist experience when visiting Singapore.

Tourist attractions in Singapore allows tourists to adjust themselves because Singapore is ranked in the top ten as a clean country in the world [1]. This gives speculation that when visiting Singapore, tourists feel very comfortable and happy traveling from one place to another and make for a good and enjoyable tourist experience when visiting Singapore.

In the tourism industry, the factors that influence tourists to revisit include satisfaction, attractiveness, accommodation, service, culture, risk [4]. [5] suggested that the factors that influence the intention of returning tourists include perceived behavioral control, perceived value, destination image and satisfaction. Meanwhile, [6] prove that country image and destination image influence revisit intention via the mediating effect of memorable tourist experience.

Tourist intention to revisit refers to the extent to which tourists have the intention to revisit the destination. According to [7], several studies have shown that past travel experiences can affect the intention of tourists to revisit a tourist destination. [8] stated that a good tourist destination can measure several important attributes in revisiting intentions. The intention to revisit can be measured by three items, namely the tendency to revisit, the desire to revisit and revisit the possibility in the near future. 
From previous discussion, it can be concluded that tourists' intention to revisit to a destination is influenced by several factors. This study aims to examine the effect of country image, self-congruity and memorable tourism experience on the revisit intention of tourists to Singapore

\section{BACKGROUND}

\subsection{Country Image}

Country image is a belief and perception that consumers have about a country. [9] defined a country's image as the total impression, belief, and perception that consumers have about a country. The image of a country is defined in various ways and is considered a multidimensional concept in existing studies ranging from social psychology and political science to communication and business [10]. [11] explained that the image of the country is the consumer's belief in a country which includes the level of economic development, standard of living, industrialization, and technological progress.

\subsection{Destination Image}

Destination image is a feeling or perception that is valued and owned by tourists about a destination visited [10]. Furthermore, [10] also defined destination image as the image of core tourism products related to tourist attractions and tourism facilities that directly meet the core needs of tourists. Destination image is generally defined as the sum of knowledge, feelings, and overall perceptions that a tourist has about a destination [12]. Consequently, destination image is one of the most studied constructs in tourism research with many different definitions and operationalizations [13].

\subsection{Self-Congruity}

Self-congruity is how a person can conform well with a brand image and a product image. [14] defined selfcongruity as a good match between self-image and product image. [15] defined that self-congruity as a match between a person's self-image and the image of a product, brand or product user. Meanwhile, [16] defined self-congruity as how much a visitor's self-concept matches the personality of a typical user of a brand.

\subsection{Memorable Tourism Experience}

Memorable Tourism Experience is the existence of an impressive tourist experience that is felt by tourists so that it becomes a memorable tourist experience for tourists who visit the place. [17] defined a memorable tourism experience as a subjective mental state felt by participants during a service meeting. [18] explained that a memorable tourism experience is a subjective evaluation of individuals who undergo events related to their tourism activities that begin before, during and after the trip. [19] defined a memorable tourism experience as a tourism experience that is remembered after the event occurred

\subsection{Revisit Intention}

Revisit intention is an intention and behavior of tourists to revisit the place within their available time. [20] explained that previous researchers have proved the determinants of revisit intention were satisfaction, service behavior, perceived value and available attractions. [21] defined that revisit intentions are repurchase intentions and behaviors that indicate a willingness to recommend and disseminate positive information for the services provided. [22] referred to revisit intention as consumers' intention to revisit within one year and their willingness to frequently travel to a destination.

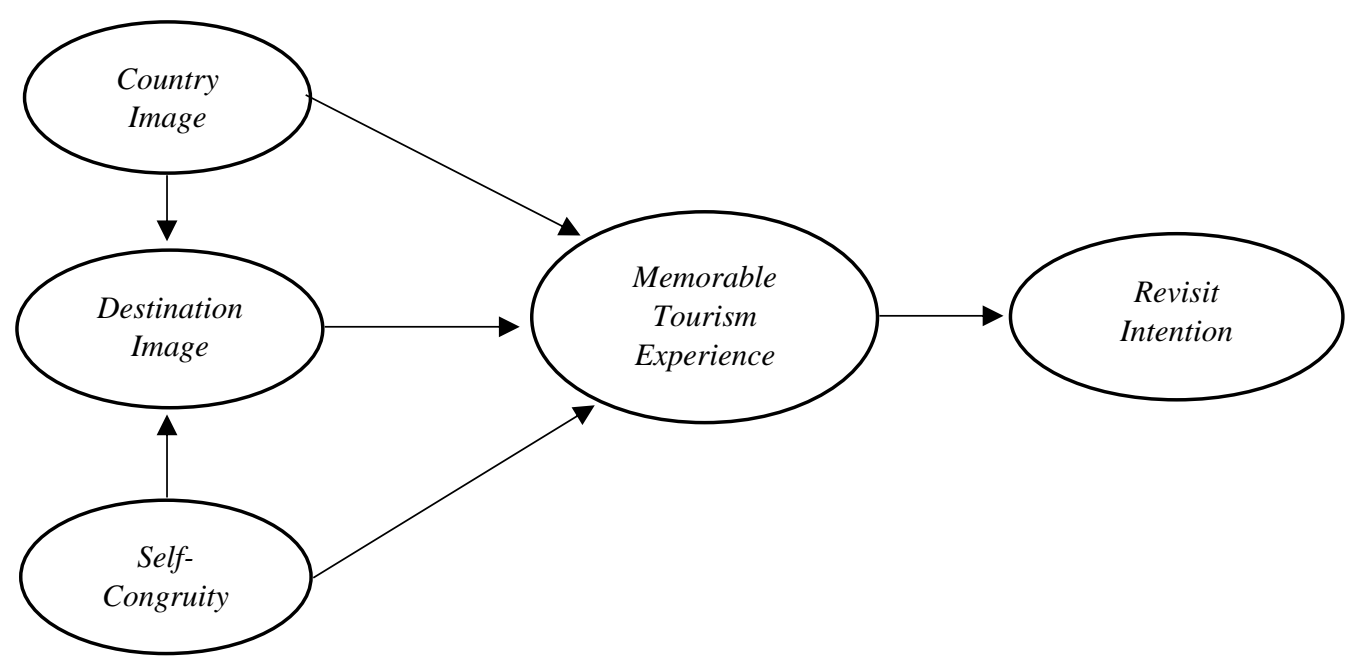

Figure 1. Research Model 
From the backgrounds and Figure 1, we proposed the research hypothesis as follows:

$\mathrm{H}_{1}$ : Country Image has a positive influence on Destination Image.

$\mathrm{H}_{2}$ : Country Image has a positive influence on Memorable Tourism Experience.

$\mathrm{H}_{3}$ : Destination Image has a positive influence on Memorable Tourism Experience.

$\mathrm{H}_{4}$ : Self-Congruity has a positive influence on Destination Image.

$\mathrm{H}_{5}$ : Self-Congruity has a positive influence on Memorable Tourism Experience.

$\mathrm{H}_{6}$ : Memorable Tourism Experience has a positive influence on Revisit Intention.

$\mathrm{H}_{7}$ : Memorable Tourism Experience has a mediating effect in the influence of Country Image on Revisit Intention.

\section{METHODS}

The population of this research are Indonesian tourists who have visited Singapore. There were 200 people participating in an online survey voluntarily. Collected data were then analysed using PLS-SEM software. The first data processing is done on the outer model to test the validity and reliability. The validity test is seen from the Average Variance Extracted value that is higher than 0.5 [23] and the loading factor value that is higher than 0.7 [24]. The results of the validity test have obtained a number for each variable at the loading factor value $>0.7$ and in the Average Variance Extracted (AVE) with a value > 0.5, thus, we can conclude that all the variables in this research are valid. In the reliability results, based on the processed results, it is stated that the number on the Cronbach's alpha and composite reliability values is $>0.6$, then the variable is reliable. The results of the validity test have obtained a number for each variable at the loading factor value $>0.7$ and in the Average Variance Extracted (AVE) with a value $>0.5$ then all the variables used are valid. In the reliability results, based on the processed results, it is stated that the score of Cronbach's alpha and composite reliability values is $>0.6$ which means that all variables are reliable.

The next data processing step is done on the inner model to test the hypothesis proposed. Tests in the first study were carried out by looking at the R-square $\left(\mathrm{R}^{2}\right)$ value with a value of 0.67 as a substantial category, 0.33 as a moderate category, and 0.19 as a weak category [23]. Furthermore, the value of the effect size $\left(\mathrm{f}^{2}\right)$ is stated at 0.02 as a weak category, 0.15 as a medium category and 0.35 as a strong category [23]. The value of predictive relevance $\left(Q^{2}\right)$ that can be seen through blindfolding if the value greater than 0 is $0.02 ; 0.15 ; 0.35$ which is categorized as weak, moderate, and strong variables [24]. At the final step, we also conducted a mediation analysis for hypothesis 7 .

\section{FINDINGS AND DISCUSSIONS}

The value of $\mathrm{R}$-square $\left(\mathrm{R}^{2}\right)$ generated in the destination image variable is 0.447 or $44.7 \%$, which means it is moderate. Furthermore, the value of the memorable tourism experience variable is 0.565 or $56.5 \%$ which is moderate and the value of the revisit intention variable is 0.450 or $45 \%$ which is moderate. In effect size $\left(\mathrm{f}^{2}\right)$, it is explained that the country image variable has a strong influence on the destination image variable with a value of 0.147 and has a strong influence on memorable tourism experience with a value of 0.171 . The self-congruity variable has a strong influence on destination image with a value of 0.453 and has a strong influence on memorable tourism experience with a value of 0.028 . The memorable tourism experience variable has a strong influence on revisit intention with a value of 0.819 . Based on the value of predictive relevance $\left(\mathrm{Q}^{2}\right)$, it is explained that the value of the destination image variable is 0.227 (medium predictive), the value of the memorable tourism experience variable is 0.312 (strong predictive), and the value of the revisit intention variable is 0.340 (strong predictive).

The results of hypothesis testing in this study can be seen from the t-statistical value and p-value contained in the bootstrapping test. The following are the results of hypothesis testing.

$\mathrm{H}_{1}$ : Country Image has a positive influence on Destination Image.

$\mathrm{H}_{2}$ : Country Image has a positive influence on Memorable Tourism Experience.

$\mathrm{H}_{3}$ : Destination Image has a positive influence on Memorable Tourism Experience.

$\mathrm{H}_{4}$ : Self-Congruity has a positive influence on Destination Image.

$\mathrm{H}_{5}$ : Self-Congruity has no influence on Memorable Tourism Experience.

$\mathrm{H}_{6}$ : Memorable Tourism Experience has a positive influence on Revisit Intention.

$\mathrm{H}_{7}$ : Memorable Tourism Experience has a mediating effect in the influence of Country Image on Revisit Intention.

The value of $\mathrm{R}$-square $\left(\mathrm{R}^{2}\right)$ generated in the destination image variable is 0.447 or $44.7 \%$, which means it is moderate. Furthermore, the value of the memorable tourism experience variable is 0.565 or $56.5 \%$ which is moderate and the value of the revisit intention variable is 0.450 or $45 \%$ which is moderate. In effect size $\left(\mathrm{f}^{2}\right)$, it is explained that the country image variable has a strong influence on the destination image variable with a value of 0.147 and has a strong influence on memorable tourism experience with a value of 0.171 .

The self-congruity variable has a strong influence on destination image with a value of 0.453 and has a strong influence on memorable tourism experience with a value of 0.028 . The memorable tourism experience variable has a strong influence on revisit intention with a value of 0.819 . Based on the value of predictive relevance $\left(Q^{2}\right)$, it is explained that the value of the destination image variable is 0.227 (medium predictive), the value of the memorable tourism experience variable is 0.312 (strong predictive), and the value of the revisit intention variable is 0.340 (strong predictive). 
Table 1. Hypotheses Testing Results

\begin{tabular}{|c|c|c|c|c|c|}
\hline Code & Hypothesis & $\begin{array}{c}\text { Path } \\
\text { Coefficient }\end{array}$ & t-statistic & p-value & Conclusion \\
\hline $\mathrm{H}_{1}$ & Country Image $\rightarrow$ Destination Image & 0.297 & 5.130 & 0.000 & Accepted \\
\hline $\mathrm{H}_{2}$ & $\begin{array}{c}\text { Country Image } \rightarrow \text { Memorable Tourism } \\
\text { Experience }\end{array}$ & 0.304 & 5.763 & 0.000 & Accepted \\
\hline $\mathrm{H}_{3}$ & $\begin{array}{c}\text { Destination Image } \rightarrow \text { Memorable Tourism } \\
\text { Experience }\end{array}$ & 0.473 & 6.878 & 0.000 & Accepted \\
\hline $\mathrm{H}_{4}$ & Self-Congruity $\rightarrow$ Destination Image & 0.521 & 9.681 & 0.000 & Accepted \\
\hline $\mathrm{H}_{5}$ & $\begin{array}{c}\text { Self-Congruity } \rightarrow \text { Memorable Tourism } \\
\text { Experience }\end{array}$ & 0.138 & 1.825 & 0.069 & Rejected \\
\hline $\mathrm{H}_{6}$ & $\begin{array}{c}\text { Memorable Tourism Experience } \rightarrow \text { Revisit } \\
\text { Intention }\end{array}$ & 0.671 & 15.295 & 0.000 & Accepted \\
\hline $\mathrm{H}_{7}$ & $\begin{array}{c}\text { Country Image } \rightarrow \text { Memorable Tourism } \\
\text { Experience } \rightarrow \text { Revisit Intention }\end{array}$ & 0.094 & 3.657 & 0.000 & Accepted \\
\hline
\end{tabular}

Based on the result of the first hypothesis, country image has a positive effect on destination image, which means that $\mathrm{H}_{1}$ was accepted. Based on research by [10], country image is defined in various ways and is considered a multidimensional concept in existing studies ranging from social psychology and political science to communication and business. Furthermore, based on research by [25], destination image is an important factor that influences the decision-making process of tourists, destination preferences, satisfaction, and behavioral intentions in the future.

The result of the second hypothesis explains that country image has a positive effect on memorable tourism experiences, which means that $\mathrm{H}_{2}$ was accepted. [10] concluded that the conceptualization of a country's image is expressed as the perception of tourists and the impression of politics, economy, technology, people's environment and other tourism environmental factors of a country. Furthermore, supported [17], memorable tourism experience was defined as a subjective mental state felt by participants during service meetings.

The result of the third hypothesis explain that destination image has a positive effect on memorable tourism experience, which means that $\mathrm{H}_{3}$ was accepted. According to [26], destination image characteristics can be classified as functional such as mental images and physical characteristics, and psychological such as general feelings and impressions of the atmosphere of the place. Furthermore, [27] defined an unforgettable experience as a visitor's memory of a trip that affects their emotions both positively and negatively, and will influence their intention to revisit the place.

The results of the fourth hypothesis explains that selfcongruity has a positive effect on destination image, which means $\mathrm{H}_{4}$ was accepted. In their research, [28] stated that self-congruity has positively influenced consumer behavior outcomes, such as attitudes, satisfaction, and loyalty in different contexts.

The results of the fifth hypothesis explains that selfcongruity has no significant effect on memorable tourism experiences, which means $\mathrm{H}_{5}$ was rejected. [29] stated that self-congruity ideally and significantly affects the evaluation of tourist consumption.

The result of the sixth hypothesis shows that memorable tourism experience has a positive effect on revisit intentions, which means that $\mathrm{H}_{6}$ was accepted. Based on the research, [10] defined that revisit intention is something that can be measured by three items, namely the tendency to revisit, the willingness to revisit, and the possibility of revisiting in the near future.

Finally, the result of the seventh hypothesis concludes there is a mediating effect of memorable tourism experience in the influence of country image on revisit intentions. [30] revealed that self-congruity has long been recognized as an important aspect in explaining and predicting various aspects of consumer behavior towards their travel experience. [19] defined seven dimensions that influence tourists' revisit intentions, which are hedonism, refreshment, local culture, meaningfulness, knowledge, involvement, and novelty. This study strengthens the findings of previous studies, stating that tourists' revisit intention can be shaped by country image with the mediation of memorable tourism experience. 


\section{CONCLUSIONS}

From this study it can be concluded that all research hypotheses are accepted except for hypothesis 5. Country image has a positive influence on destination image and memorable tourism experience, destination image has a positive influence on memorable tourism experience, selfcongruity has a positive influence on destination image, memorable tourism experience has a positive influence on revisit intention and lastly, memorable tourism experience has a mediating effect in the influence of country image on revisit intention. Singapore as a tourist destination continues to improve its services broadly. This research was conducted during the COVID-19 pandemic, however, the respondents' impression on Singapore remains attached. This shows the importance of creating tourism offerings that are able to form memories. Memorable tourism experience can boost tourists' revisit intention int the future. For further research, we suggest to explore other variables such as customer 's involvement during their visit on a destination and also novelty value of destination's offerings.

\section{ACKNOWLEDGMENT}

This work was supported by the Directorate of Research and Community Engagement of Universitas Tarumanagara.

\section{REFERENCES}

[1] http://travel.tribunnews.com

[2] http://hipwee.com

[3] http://travel.kompas.com

[4] Viet, B.N., Dang, H.P., and Nguyen, H.H. (2020). Revisit intention and satisfaction: The role of destination image, perceived risk, and cultural contact. Cogent Business \& Management, Vol, 7 (1), 1796249, DOI: 10.1080/23311975.2020.1796249.

[5] Abbasi, G.A., Kumaravelu, J., Goh, Y.N., and Dara Singh, K.S. (2020). Understanding the intention to revisit a destination by expanding the theory of planned behaviour (TPB)

[6] Zhang, H., Wu, Y., Buhalis, D. (2018). A model of perceived image, memorable tourism experiences and revisit intention. Journal of Destination Marketing \& Management, Vol. 8 (1): 326-336.
[7] Bonn M.A., Joseph-Mathews, S.M., Dai M., Hayes S., Cave J. (2007) Heritage / Cultural Attraction Atmospherics: Creating the Right Environment for the Heritage/Cultural Visitor. Journal of Travel Research. 2007;45(3):345-354. DOI: 10.1177/0047287506295947

[8] Horng, J. S. (2012). Understanding the impact of culinary brand equity and destination familiarity on travel intentions. In Tourism Management.

[9] Roth, K.P., and Diamantopoulos, A. (2007) Advancing the country image construct. Journal of Business Research Volume 62 (7): 726-740.

[10] Zhang, H., Xu, F., Leung, H.H., and Cai, L.A. (2018). The influence of destination-country image on prospective tourists' visit intentions: Testing three competing models. . Asia Pacific Journal of Tourism Research, 21(7), 811-835.

[11] Wang, C.L. \& Li, D., Barnes, B.R. \& Ahn, J. (2012). Country image, product image and consumer purchase intention: Evidence from an emerging economy. International Business Review, Elsevier, vol. 21(6), pages 1041-1051.

[12] Fakeye, P. C. (1991). Image differences between prospective, first-time, and repeat visitors to the Lower Rio Grande Valley. Journal of Travel Research, 30(2), 10-16.

[13] Tasci, A.D.A., Gartner, W.J., and Cavusgil, S.T. (2007) Conceptualization and Operationalization of Destination Image. Journal of Hospitality \& Tourism Research 31(2):194-223. DOI: $10.1177 /$ 1096348006297290

[14] Ekinci, Y., Dawes, P.L. and Massey, G.R. (2008), "An extended model of the antecedents and consequences of consumer satisfaction for hospitality services", European Journal of Marketing, Vol. 42 No. $1 / 2$, pp. 35-68. https://doi.org/10.1108/ 03090560810840907

[15] Sirgy, M.J., and Su, C. (2000). Destination Image, Self-Congruity, and Travel Behavior: Toward an Integrative Model. Journal of Travel Research 38 (4):340-352. DOI:10.1177/004728750003800402

[16] Helgeson, J.G. and Supphellen, M. (2004) A Conceptual and Measurement Comparison of SelfCongruity and Brand Personality: The Impact of Socially Desirable Responding. International Journal of Market Research, 46, 205-233. 
[17] Otto, J. E. \& Ritchie, J. R. B. (1996). The service experience in tourism. Tourism Management, 17(3), $165-174$.

[18] Tung, V.W.S., \& Ritchie, J. R. (2011). Exploring the essence of memorable tourism experiences. Annals of Tourism Research, 38 (34), 1367-1386.

[19] Kim, J.-H., Ritchie, J. R. B., \& McCormick, B. (2012). Development of a Scale to Measure Memorable Tourism Experiences. Journal of Travel Research, 51(51), 12-25.

[20] Petrick, J., Morals, D., and Norman, W. (2001). An Examination of the Determinants of Entertainment Vacationers' Intentions to Revisit. Journal of Travel Research 40(1): 41-48. DOI: 10.1177/ 004728750104000106.

[21] Teng, C.-C., \& Kuo, T.-H. (2011). The combined effects of employee hospitality performance, environment, and entertainment on customer affective response and revisit intention in restaurants. Advances in Hospitality and Tourism Marketing and Management Conference Proceeding, (3-7).

[22] Baker, D. A., \& Crompton, J. L. (2000). Quality, satisfaction and behavioral intention. Annals of Tourism Research, 27(3), 785-804.

[23] Hair, J. F. Jr., Ringle, C.M., and Sarstedt, M. (2011) PLS-SEM: Indeed a silver bullet. The Journal of Marketing Theory and Practice 19(2): 139-151. DOI: 10.2753/MTP1069-6679190202.

[24] Henseler, J., Ringle, C. M., and Sinkovics, R. R., (2009) The Use of Partial Least Squares Path Modeling in International Marketing. Advances in International Marketing (pp.277-319). Emerald JAI Press. DOI:10.1108/S1474-7979(2009)0000020014.

[25] Hair, J. F., Sarstedt, M, Ringle, C. M., and Mena, J.A. (2012). An Assessment of the Use of Partial Least Squares Structural Equation Modeling in Marketing Research Journal of the Academy of Marketing Science 40(3):414-433. DOI: 10.1007/s11747-011-0261-6.

[26] Tan, W., and Wu, C.E. (2016). An investigation of the relationships among destination familiarity, destination image and future visit intention. Journal of Destination Marketing \& Management, 5(3), 214-226.

[27] Phucharoen, P., Sriboonlue, U., and Assarut, N. (2016). The effects of destination image, destination personality and self-congruity on tourists' intention. IJABER Vol. 14 (13): 8991-9007.
[28] Shen, Y. (2016). Perceived Value in Tourism Experience. Travel and Tourism Research Association: Advancing Tourism Research Globally. 8. https:// scholarworks.umass.edu/ttra/2016/Grad_Student_Work shop/8

[29] Kang, J., Tang, L., and Lee, J.Y. (2015). "Selfcongruity and functional congruity in brand loyalty". Journal of Hospitality \& Tourism Research, Vol. 39 No. 1, pp., 105-131. https://doi.org/10.1177/ 1096348012471377

[30] Frias, D. M., Castaneda, J-A., del Barrio-Garcia, S., Lopez-Moreno, L. (2020). The effect of self-congruity and motivation on consumer- based destination brand equity. Journal of Vacation Marketing, 26(3), 287- 304. 